\title{
İRON SAZLIĞI'NDA (BİTLİS, TÜRKIYYE) YETİŞEN KARABURUN BALIĞININ [Chondrostoma regium (Heckel, 1843)] BESİN ÖĞELERİNİN İNCELENMESİ
}

\author{
Şeyda Kaya ${ }^{1^{*}}$, Hülya Durmaz Bekmezci ${ }^{2}$ \\ ${ }^{1}$ Muş Alparslan Üniversitesi, Sağlık Bilimleri Fakültesi, Muş, Türkiye \\ ${ }^{2}$ Bitlis Eren Üniversitesi, Bitlis, Türkiye
}

Geliş / Received: 28.08.2020; Kabul / Accepted: 16.02.2021; Online bask1 / Published online: 12.03.2021

Kaya, Ş., Durmaz-Bekmezci, H. (2021). İron sazlığı'nda (Bitlis, Türkiye) yetişen karaburun balığının [Chondrostoma regium (Heckel, 1843)] besin öğelerinin incelenmesi. GIDA (2021) 46(2) 351-357 doi: 10.15237/gida. GD20103.

Kaya, S., Durmaz-Bekmezci, H. (2021). Investigation of proximate composition of brond-snout [Chondrostoma regium (Heckel, 1843)] growing in iron reeds (Bitlis, Turkey). GIDA (2021) 46(2) 351-357 doi: 10.15237/gida. GD20103.

\section{ÖZ}

İron Sazlı̆̆ Bitlis İli’nde yer alan Türkiye'nin önemli sulak alanlarından biridir. Alanda yaşayan karaburun balı̆ı1 (Chondrostoma regium Heckel, 1843) bölge halk1 tarafindan yoğun bir şekilde tüketilmektedir. Bu çalışmada, balıkçılar tarafindan Kasım (2019) tarihinde yakalanan balıkların besin kompozisyonunun belirlenerek yöre halkı için besinsel değerinin incelenmesini amaçlanmıştır. Bu kapsamda; balıkçıdan temin edilen balıklar soğuk zincir ile laboratuvara getirilmiş ve disekte edilerek analizlere kadar $-18{ }^{\circ} \mathrm{C}$ 'de saklanmıştr. Analizler sonucunda numunelerde protein $\% 18.62 \pm 2.10$, yağ $\% 2.61 \pm 1.08$, kül $\% 1.44 \pm 0.35$,

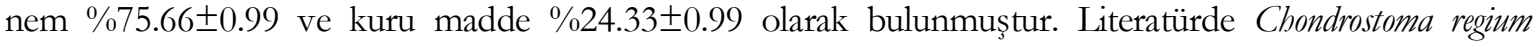
(Heckel, 1843)'un besin değerlerinin incelendiği çalışmalar oldukça kısıtlı olup çalışmanın bu anlamda literatüre katk1 sağlayabileceği düşünülmüştür.

Anahtar kelimeler: İron Sazlığı, Chondrostoma regium, Karaburun Balığı, Besin Değerleri, Bitlis

\section{INVESTIGATION OF PROXIMATE COMPOSITION OF BROND-SNOUT [Chondrostoma regium (Heckel, 1843)] GROWING IN IRON REEDS (BITLIS, TURKEY)}

\begin{abstract}
Iron Reeds, located in Bitlis Province is one of the most important wetlands in Turkey. Karaburun fish (Chondrostoma regium Heckel, 1843) living in the area is heavily consumed by the people of the region. This study aimed to determine the nutritional composition of the fishes caught by fishermen in November (2019) and to examine the nutritional value for the local people. The fish obtained from fishermen were brought to the laboratory with a cold chain, dissected and stored at $-18^{\circ} \mathrm{C}$ until analysis. As a result of the analysis, the average levels of crude protein, lipid, ash, moisture and dry matter were found to be; $18.62 \pm 2.10 \%, 2.61 \pm 1.08 \%, 1.44 \pm 0.35 \%, 75.66 \pm 0.99 \%, 24.33 \pm 0.99 \%$, respectively. Studies relating the nutritional values of Chondrostoma regium (Heckel, 1843) are quite limited in the literature, and it is thought that study may contribute to the literature in this area.
\end{abstract} Keywords: Iron Reeds, Chondrostoma regium, Brond-Snout, Proximate Composition, Bitlis

\footnotetext{
* Yazışmalardan sorumlu yazar / Corresponding author

17: s.gungor@alparslan.edu.tr, (1): (+90) 055314789 86, 04362494949 县: (+90) 4362491313
}

Şeyda Kaya; ORCID no: 0000-0003-0333-8966

Hülya Durmaz Bekmezci; ORCID no: 0000-0001-5164-7750 


\section{GİRIŞ}

Balıketi, sağl1klı ve dengeli bir beslenme düzeni için son derece önemli ve temel bir besin öğesidir (Baysal vd., 2013). Protein bakımından zengin, az yağlı ve omega-3 yağ asitleri açısından son derece zengin olan balıketi tüketimi, başta kardiyovasküler rahatsızlıklar ve obezite olmak üzere pek çok hastalıktan korunmada etkin rol oynamaktadır (Domingo, 2007; Burger ve Gochfeld,2009).

Doğu Anadolu Bölgesinde Bitlis ili/Güroymak ilçesi ile Muş ili/Korkut ilçesi arasında bulunan, oldukça geniş bir fauna ve floraya sahip, RAMSAR sözleşmesi açısından da önemli sulak alanlardan biri olan İron Sazlığı, bölge halk1 tarafindan ciddi bir balık tüketim kaynağı olarak görülmektedir (Eken vd., 2006; Anonymous, 2019; Türkdoğan, 2012; Avşin vd., 2019). Doğa koruma Şubesinden alınana sözlü bilgiye göre sazlık içerisinde pek çok balık türü yaşamakta ve karaburun balığ1 (Chondrostoma regium Heckel, 1843) özellikle sonbahar mevsiminde bölge halk1 tarafından yoğun olarak tüketilmektedir.

Bu çalışmada İron Sazlığı'nda yetişen ve bölgede yoğun olarak tüketilen Chondrostoma regium (Heckel, 1843)'un besin kompozisyonunun incelenmesi amaçlanmıştr.

\section{MATERYAL VE YÖNTEM}

$\mathrm{Bu}$ çalışmada özellikle balığın bol ve lezzetli olduğu sonbahar mevsiminde (Kasım, 2019) bölgedeki yerel balıkçıların serpme balıkçılığ ile avladıkları ve satışa sundukları balıklardan en fazla olanı seçilerek, 1s1 yalıtımlı kaplarda soğuk zincir ile Bitlis Eren Üniversitesi Çevre Mühendisliği Laboratuvarına getirilmiştir. Yirmi adet balık örneği ilk olarak numaralandırılmış, musluk suyu ile yıkanmış ve filtre kâğıdıyla kurutulmuştur. Tam boy ve çatal boyları milimetrik cetvel ile total ağırlıkları ve gonad ağıllkkları $0.01 \mathrm{gr}$ hassasiyetli Akpınar marka hassas terazi ile ölçülmüsstür. Gonad ağırlıkları ve görünümlerine bakılarak balıklarda cinsiyet tayini yapılmışır. Balıklanın yenilebilen tüm kas dokuları çıkartılarak saf su ile yıkanmış önce polietilen streç film ile ardından alüminyum folyo ile paketlenmiş ve bazı analizler bir başka birimde gerçekleşeceği için analiz gününe kadar $-18{ }^{\circ} \mathrm{C}$ 'de saklanmıştur.

Besin kompozisyonu analizleri kapsamında ham protein, yağ, toplam kül, nem ve toplam kuru madde oranları incelenmiştir. Ham protein yüzdesi tayini ve yağ yüzdesi tayini Bingöl Üniversitesi Merkezi Laboratuvar Uygulama ve Araşturma Merkezi'nde gerçekleştirilmiştir. Ön işlemler kapsamında $-18{ }^{\circ} \mathrm{C}$ 'den alınan numuneler ev tipi blender ile homojenize edilip $1.5 \mathrm{ml}$ 'lik eppendorf ve $15 \mathrm{ml}$ 'lik polipropilen falkon tüplere konularak 1sı yalıtımlı kapta buz aküsü ile birlikte paketlenmiş ve soğuk zincir ile ilgili birime gönderilmiştir. İlgili birimde ham protein yüzdesinin analizinde Gerhardt-Dumaterm marka 124 seri numaralı protein analiz cihazı kullanılmıştır. Uygulamada Dumas yönteminin temel prensipleri esas alınmış, 0.20-0.25 g numune alınarak 800-900 ${ }^{\circ} \mathrm{C}$ 'de saf oksijenle yakılmıs bu sayede gıda içerisindeki tüm azot formlarının azot oksit gazına dönüşmesi sağlanmıştır. Daha sonra bu gazlar elemental azot formuna indirgenerek gıda içerisindeki toplam azot miktarı saptanmıştır. Elde edilen \%nitrojen balıklar için 6,25 olan protein çevirme faktörü ile çarpılmış ve numunelerin ham protein yüzdesi bulunmuştur (Olgun vd., 2013). Yağ yüzdesinin analizi ise Velp Scizentifica marka 148 seri numaralı ekstraksiyon cihazıyla yapılmıştır. Yağ yüzdesinin analizinde soxhlet ekstraksiyonu yönteminin temel prensipleri esas alınmıştır. Sabit tartıma gelinceye kadar etüvde kurutulan numuneler soxhlet cihazı içerisinde kimyasal çözücüler ile karıştırılarak numuneden yağın ekstraksiyonu sağlanmıştır. Daha sonra ise çözücü uçurularak kalan numunenin tartımı ile numunedeki yağ yüzdesi saptanmıştır (Büyüktuncel, 2012).

Nem ve kuru madde ve kül analizleri ise AOAC (1990)'a göre Bitlis Eren Üniversitesi Beslenme ve Diyetetik Laboratuvarında tarafimızca gerçekleştirilmiştir. Nem ve kuru madde analizlerinde sıcak hava ile kurutma yöntemi kullanılmıştır. Daha önceden daraları ölçülen petri kaplarına örneklerden 5'er g konulmuş, kaplar maşa ile tutularak önceden 1sıtılmış Wisd marka etüve yerleştirilmiş ve $105{ }^{\circ} \mathrm{C}$ 'de 18 saat boyunca sabit tartıma gelinceye kadar bekletilmiştir. 
Ardından kaplar tekrar hassas terazide tartılmışırı. Aradaki farkın toplam ağırllğa bölünüp 100 ile çarpılması ile örneklerin nem yüzdesi tespit edilmiştir. Kalan yüzdelik kısım ise toplam kuru madde yüzdesini ifade etmiştir. Kül miktarı tayini için ise örnekler Akpınar marka hassas terazide tartılarak daha önceden darası alınmış porselen krozeler içerisine 1-2'şer $g$ alınmış, kül yakma fırınına yerleştirilip $550{ }^{\circ} \mathrm{C}$ 'de 8 saat boyunca yakılmıştır. Ardından örnekler soğutularak tartılmıştır. Toplam kül miktarı, porselen krozelerin kül firınından çıttıktan sonraki ağırllğının dara ağırlı̆̆ından çıkartılmasıyla bulunmuştur. Bu ağırlığın başlangiçta kullanılan örnek ağırllğına bölünüp 100 ile çarpılması ile de örnekteki kül miktarının yüzdelik oranı saptanmıştır (AOAC, 1990; Gökalp ve Kaya, 1993).

Verilerin istatistiksel analizi SPSS 23 (Statistical Package for the Social Sciences) paket program1 ile yapılmıştur. Sonuçlar \%95 güven aralığında, $P$ $<0.05$ anlamllık düzeyinde değerlendirilmiştir. Verilerin normallik testleri örnek sayıs $25^{\prime}$ ten küçük olduğu için Shapiro-Wilk testi kullanılarak ve Skewness-Kurtosis katsayılanı incelenerek yapılmıştrr. Skewness-Kurtosis katsayılarının -2 ile +2 arasında olduğu durumlarda verilerin normal dağılım gösterdiği kabul edilmiştir (George ve Mallery, 2010). Normal dağılım gösteren değişkenlerde parametrik istatistiksel yöntemlerden bağımsız örneklemler $t$ testi ile dişi ve erkler gruplar arasındaki farkların anlamlı olup olmadığı analiz edilmiştir.

\section{BULGULAR VE TARTIŞMA}

Bu çalışmada kullanılan balıklarının $(n=20) \% 80$ ’i dişi, \%20'si erkektir. Balıkların besin içerikleri analizleri tekrarsız olarak gerçekleştirilmiş olup analizler sonucunda elde edilen bulgular oransal olarak, cinsiyet bazında ve populasyon genelinde olmak üzere Çizelge 1'de verilmiştir. Balıklanın besin değerlerine ait verilerin normallik testine ait sonuçlar Çizelge 2'de verilmiş olup verilerin tümünün normallik varsayımını karşıladığı görülmüştür. Balıkların besin değerlerinin cinsiyet bazında değerlendirildiği bağımsız örneklemler $\mathrm{t}$ testine ait sonuçlar Çizelge 3’te verilmiştir.

Çizelge 1. Chondrostoma regium (Heckel, 1843)'un ortalama yüzde besin değerleri Table 1. Proximate composition of Chondrostoma regium (Heckel, 1843)

\begin{tabular}{lccccc}
\hline & $\begin{array}{c}\text { Protein } \% / \\
\text { Protein } \%\end{array}$ & $\begin{array}{c}\text { Yağ } \% / \\
\text { Lipid } \%\end{array}$ & $\begin{array}{c}\text { Nem } \% / \\
\text { Moisture } \%\end{array}$ & $\begin{array}{c}\text { Kül \% / } \\
\text { Ash } \%\end{array}$ & $\begin{array}{c}\text { Kuru madde } \% / \\
\text { Dry matter } \%\end{array}$ \\
\hline $\begin{array}{l}\text { Dişi }(\mathrm{n}=16) / \\
\text { Female }(n=16)\end{array}$ & $19.02 \pm 2.10$ & $2.50 \pm 0.97$ & $75.56 \pm 0.89$ & $1.46 \pm 0.37$ & $24.43 \pm 0.89$ \\
\hline $\begin{array}{l}\text { Erkek }(\mathrm{n}=4) / \\
\text { Male }(n=4)\end{array}$ & $17.04 \pm 1.34$ & $3.07 \pm 1.55$ & $76.04 \pm 1.44$ & $1.34 \pm 0.21$ & $23.95 \pm 1.44$ \\
\hline $\begin{array}{l}\text { Genel }(\mathrm{n}=20) / \\
\text { All }(n=20)\end{array}$ & $18.62 \pm 2.10$ & $2.61 \pm 1.08$ & $75.66 \pm 0.99$ & $1.44 \pm 0.35$ & $24.33 \pm 0.99$ \\
\hline
\end{tabular}

Yapılan analizlerde, ortalama protein oranı dişi baliklarda \%19.02 \pm 2.10 , erkek baliklarda $\% 17.04 \pm 1.34$, populasyon genelinde ise $\% 18.62 \pm 2.10$ olarak saptanmiştur. Balıklarda protein oranının dişi ve erkek balıklarda anlamlı bir şekilde farklılaşmadığı görülmüştür $(P=0.094)$. Ortalama yağ oranı dişi balıklarda $\% 2.50 \pm 0.97$, erkek balıklarda \%3.07 \pm 1.55 , populasyon genelinde ise $\% 2.61 \pm 1.08$ olarak bulunmuştur. Balıklarda yăg oranının dişi ve erkek balıklarda anlamlı bir şekilde farklılaşmadığı görülmüştür ( $P$ $=0.365$ ). Ortalama nem oranı dişi balıklarda $\% 75.56 \pm 0.89$, erkek balıklarda \%76.04 \pm 1.44 , populasyon genelinde ise $\% 75.66 \pm 0.99$ olarak bulunuştur. Balıklarda nem oranının dişi ve erkek balıklarda anlamlı bir şekilde farklılaşmadığı görülmüştür $(P=0.408)$. Ortalama kül oranı dişi balıklarda \%1.46 \pm 0.37 , erkek balıklarda $\% 1.34 \pm 0.21$, populasyon genelinde ise $\% 1.44 \pm 0.35$ olarak bulunuştur. Balıklarda nem oranının dişi ve erkek balıklarda anlamlı bir şekilde farklılaşmadığ1 görülmüştür ( $P=0.554$ ) (Çizelge 3). 
Çizelge 2. Balıkların besin değerlerinin normallik analizi sonuçları

Table 2. Results of the normality analysis of nutritional values of fish

\begin{tabular}{llllll}
\hline & $\begin{array}{l}\text { Protein } \% / \\
\text { Protein \% }\end{array}$ & $\begin{array}{l}\text { Yağ } \% / \\
\text { Lipid } \%\end{array}$ & $\begin{array}{l}\text { Nem } \% / \\
\text { Moisture } \%\end{array}$ & $\begin{array}{l}\text { Kül \% / } \\
\text { Ash \% }\end{array}$ & $\begin{array}{l}\text { Kuru madde \% / } \\
\text { Dry matter \% }\end{array}$ \\
\hline$P$ & 0.122 & 0.021 & 0.394 & 0.423 & 0.394 \\
\hline Skewness & 0.293 & 1.170 & 0.292 & 0.476 & -0.292 \\
\hline Kurtosis & -1.312 & 1.222 & -1.070 & -0.593 & -1.070 \\
\hline${ }^{*}<0.05$ & & & &
\end{tabular}

Çizelge 3. Balıkların besin değerlerinin cinsiyet bazında değerlendirildiği t-testi sonuçları Table 3. T-test results evaluating the nutritional values of fish on the basis of gender

\begin{tabular}{|c|c|c|c|c|c|c|}
\hline $\begin{array}{l}\text { Parametre / } \\
\text { Parameter }\end{array}$ & $\begin{array}{l}\text { Cinsiyet / } \\
\text { Gender }\end{array}$ & $\mathrm{N}$ & $X$ & SD & $\mathrm{F}$ & $P$ \\
\hline Protein / & $\mathrm{D}$ & 16 & 19.0201 & 2.10827 & \multirow{2}{*}{2.550} & \multirow{2}{*}{.094} \\
\hline Protein & $\mathrm{E}$ & 4 & 17,0455 & 1,34106 & & \\
\hline Yağ / & $\mathrm{D}$ & 16 & 2.5062 & .97116 & \multirow{2}{*}{1.173} & \multirow{2}{*}{.365} \\
\hline Lipid & $\mathrm{E}$ & 4 & 3.0720 & 1.55308 & & \\
\hline Nem / & $\mathrm{D}$ & 16 & 75.5656 & .89382 & \multirow{2}{*}{4.110} & \multirow{2}{*}{.408} \\
\hline Moisture & $\mathrm{E}$ & 4 & 76.0425 & 1.44133 & & \\
\hline Kuru Madde / & $\mathrm{D}$ & 16 & 24.4344 & .89382 & \multirow{2}{*}{4.110} & \multirow{2}{*}{.408} \\
\hline Dry matter & $\mathrm{E}$ & 4 & 23.9575 & 1.44133 & & \\
\hline Kül / & $\mathrm{D}$ & 16 & 1.4659 & .37920 & \multirow{2}{*}{1.856} & \multirow{2}{*}{.554} \\
\hline Ash & $\mathrm{E}$ & 4 & 1.3454 & .21585 & & \\
\hline
\end{tabular}

*D=dişi / female, $\mathrm{E}=$ erkek / male

$* P<0.05$

Literatürde Chondrostoma regium (Heckel, 1843)'un besin değerlerinin incelendiği çalıșmalar oldukça kısıtlı olup Çizelge 4'te derlenmiştir. Balıkların besinsel bileşimlerini etkileyen pek çok faktör bulunmaktadır. Bunlar arasında; üreme dönemi, ortamin besin stoku, sicaklik, mevsim, ortamın kirliliği, balığın yaşı, cinsiyeti veya içinde bulunduğu ortam koşulları sayılabilir (Köprücü ve Özdemir, 2003; Güneş, 2007). İron Sazlı̆̆1'nda yetişen Chondrostoma regium (Heckel, 1843)'un besin değerleri aynı tür üzerinde yapılan çalışmalarla (Çizelge 4) karşılaştırıldığında; protein, nem ve kül oranlanı açısından benzer olduğu fakat sonbahar mevsimi ve kasım ayı için yağ oranı açısından kısmen yüksek olduğu görülmektedir. $\mathrm{Bu}$ durumun sebebi olarak bölgedeki balıkların bölgenin yüksek rakımından dolayı suların erken soğuması ile diğer bölgelerdeki balıklardan daha erken yağ tutmaya başliyor olabileceği düşünülmüştür. Diğer taraftan Kara (2001), Chondrostoma regium (Heckel, 1843)'un kas dokusundaki yağ asidi miktarlarını üreme periyotları bazında incelemiş, yağ asidi miktarının üreme sonrasında anlamlı şekilde azaldığını bildirmiștir. Çalıșmamızda balıklarda yaş tayini yapılmaması nedeniyle balıkların eşeysel olgunluğa ulaşıp ulaşmadığı bilinmemektedir. $\mathrm{Bu}$ nedenle, farklı çalışma alanlarında (Kaçar vd., 2018; Çoban ve Şen, 2006; Oymak, 2001) üreme dönemi Mart-Haziran aras1 olarak bildirilen Chondrostoma regium (Heckel, 1843)'un üreme dönemi sonrasında yă̆ depolarını eritmiş, ardından yeniden yağlanmaya başlamış ve avlandığı Kasım ayında bu kısmi yüksek yă̆ yüzdesine sahip olmuş olabileceği hipotezimizi destekleyebilecek güçlü bir kanıt bulunmamaktadır. 
Çizelge 4. Chondrostoma regium (Heckel, 1843)'a ait önceki çalişmalar Table 4. Previous studies of Chondrostoma regium (Heckel, 1843)

\begin{tabular}{|c|c|c|c|c|c|}
\hline & $\begin{array}{l}\text { Protein \% / } \\
\text { Protein \% }\end{array}$ & $\begin{array}{l}\text { Yağ \% / } \\
\text { Lipid \% }\end{array}$ & $\begin{array}{l}\text { Nem \% / } \\
\text { Moisture \% }\end{array}$ & $\begin{array}{l}\text { Kül \% / } \\
\text { Ash \% }\end{array}$ & $\begin{array}{l}\text { Karbonhidrat- } \\
\text { Kas Glikojen \% / } \\
\text { Carbobydrate- } \\
\text { Muscle Glycogen \% }\end{array}$ \\
\hline $\begin{array}{l}\text { Özy1lmaz } \\
\text { vd., (2016) }\end{array}$ & $\begin{array}{l}\text { (Kasim / } \\
\text { November) } \\
18.48 \pm 0.38\end{array}$ & $\begin{array}{l}\text { (Kasim } \\
\text { November) } \\
2.76 \pm 0.13\end{array}$ & $\begin{array}{l}\text { (Kasim / } \\
\text { November) } \\
77.73 \pm 0.91\end{array}$ & $\begin{array}{l}\text { (Kasim / } \\
\text { November) } \\
0.77 \pm 0.04\end{array}$ & $\begin{array}{l}\text { (Kasim / } \\
\text { November) } \\
0.55 \pm 0.03\end{array}$ \\
\hline $\begin{array}{l}\text { (Kaçar vd., } \\
\text { 2018) }\end{array}$ & & $\begin{array}{l}\text { (Kasim / } \\
\text { November) } \\
0.92 \pm 0.23\end{array}$ & & & \\
\hline (Dağll, 2009) & & $\begin{array}{l}\text { Sonbahar / } \\
\text { Autumn) } \\
1.40 \pm 0.15 \\
\end{array}$ & & & $\begin{array}{l}\text { (Sonbahar / } \\
\text { Autumn) } \\
\% 0.07 \pm 0.005\end{array}$ \\
\hline (Kaya, 2017) & & $\begin{array}{l}\text { (Kasim / } \\
\text { November) } \\
\mathrm{D}=\% 1.46 \pm 0.04 \\
\mathrm{E}=\% 2.14 \pm 0.10\end{array}$ & & & \\
\hline $\begin{array}{l}\text { (Erdoğrul } \\
\text { vd., 2005) }\end{array}$ & & $\begin{array}{l}\text { (Ocak-Haziran/ } \\
\text { January-June) } \\
1.63\end{array}$ & & & \\
\hline
\end{tabular}

$* \mathrm{D}=$ dişi / female, $\mathrm{E}=$ erkek / male

\section{SONUÇ}

Bu çalışmada; Kasım (2019) ayında bölge halkının balık tüketim kaynağı olan İron Sazlı̆̆ı'dan yerel balıkçılar tarafindan serpme ağ ile avlanan Chondrostoma regium (Heckel, 1843)'un besin kompozisyonu incelenmiş ve literatür verileri ile karşılaştırılmıştır. Yapılan analizlerde İron Sazliğ'nda yetişen Chondrostoma regium (Heckel, 1843 ')un protein oranı $\% 18.62 \pm 2.10$, yağ oranı $\% 2.61 \pm 1.08$, nem oran1 $\% 75.66 \pm 0.99$, kül oran1 $\% 1.44 \pm 0.35$ ve kuru madde oran $\% 24.33 \pm 0.99$ olarak saptanmıştır. Ayrıca bu oranların dişi ve erkek bireyler arasinda anlamlı bir şekilde farklılaşmadı̆̆1 görülmüştür. Diğer yandan verilerimizin, Chondrostoma regium (Heckel, 1843)'un besin değerlerinin incelendiği diğer çalışmalarla benzer olduğu görülmüş, kısmen yüksek olan yağ oranının ise kabul edilebilir olduğu ve bu durumun çevresel farkllıklarla açıklanabileceği düşünülmüsstür.

$\mathrm{Bu}$ çalışmada yöre halkı tarafindan yoğun bir şekilde tüketilen ve ekonomik öneme sahip olan Karaburun balığının iyi bir besin bileşimine sahip olduğu anlaşılmış olup, ekosistemin devamlılığ ile besin kaynaklarının ve türlerin sürdürülebilirliğinin sağlanabilmesi için etkili su yönetim planlarının ve balıkçlık stratejilerinin geliştirilmesi tarafımızca önerilmektedir.

\section{ÇIKAR ÇATIŞMASI BEYANI}

Yazarlar, bu makale ile ilgili başka kişi veya kurumlar ile çıkar çatışması olmadığını beyan eder.

\section{YAZAR KATKILARI}

Bu çalısma Şeyda Kaya'nın yüksek lisans tezinin bir bölümünden üretilmiştir. Tüm yazarlar bu çalışmanın planlanmasında, saha araştırmalarında, makalenin taslağının oluşturulmasında, yazılmasinda ve yayınlanmasinda katk1 sağlamışlardır. Ayrıca çalışmaya olan teknik desteklerinden ötürü Sayın Erdem Kaya'ya teşekkür ederiz.

\section{KAYNAKÇA}

Anonymous, (2019). T.C. Tarim ve Orman Bakanlığ1, Su Yönetimi Genel Müdürlüğü, Su Kalitesi Yönetimi Hizmet İçi Eğitimi. 3-5 Nisan 2019, Antalya. https://www.tarimorman.gov.tr/ SYGM/Belgeler/Su Kalitesi HIE Haber 
2019/Sulak Alanlar ve Onemi.pdf (Erişim Tarihi: 26 Eylül 2019).

AOAC (1990). Official Methods of Analysis AOAC INTERNATIONAL. 15th Edition. Washington DC, the USA.

Avşin, N., Kıvrak, A., Kavak, E. (2019). Budaklı (Bitlis) kaplıcasının jeokimyasal özellikleri ile alanın jeolojik ve coğrafi yapısı arasındaki ilişki. Van Yüzüncü Yul Üniversitesi Sosyal Bilimler Enstitüsü Dergisi, Ek-1(Özel Sayı): 105-124.

Baysal, A., Aksoy, M., Besler, T.H., Bozkurt, N., Keçecioğlu, S., Mercanligil, S.M., Merdol, T.K., Pekcan, G., Yildız, E. (2013). Diyet el kitabı. Hatipoğlu Yayınları, Ankara, Türkiye, 654s. ISBN: 9789757527978

Burger, J., Gochfeld, M. (2009). Perceptions of the risks and benefits of fish consumption: individual choices to reduce risk and increase health benefits. Environ Res, 109(3): 343-349, doi: 10.1016/j.envres.2008.12.002.

Büyüktuncel, E. (2012). Gelişmiş ekstraksiyon teknikleri 1. Hacettepe Üniversitesi Ecracullk. Fakültesi Dergisi, 32(2): 209-242.

Çoban, M.Z., Şen, D. (2006). Keban Baraj Gölü'nde yaşayan Chondrostoma regium (Heckel, 1843)'un üreme özellikleri. Firat Üniversitesi Fen ve Mühendislik Bilimleri Dergisi, 18(1): 41-48.

Dağlı, M. (2009). Karakaya Baraj Gölü'nde yaşayan Acanthobrama marmid (Heckel, 1843), Leuciscus cephalus (Nordmann, 1840), Chondrostoma regium (Heckel, 1843)'un total glikojen, total lipid ve total yă asidi bileşiminin mevsimsel incelenmesi. İnönü Üniversitesi Fen Bilimleri Enstitüsü Biyoloji Anabilim Dalı Doktora Tezi, Malatya, Türkiye, 143s.

Domingo, J.L. (2007). Omega-3 fatty acids and the benefits of fish consumption: is all that glitters gold?. Environ Int, 33(7): 993-998, doi: 10.1016/j.envint.2007.05.00.

Eken, G., Bozdoğan, M., İsfendiyaroğlu, S., Kıllı̧, D.T., Lise, Y. (eds.). (2006). Türkiye'nin önemli doğa alanlar. Doğa Derneği, Ankara, Türkiye, 79s.

Erdoğrul, O., Covaci, A., Schepens. P. (2005). Levels of organochlorine pesticides, polychlorinated biphenyls and polybrominated diphenyl ethers in fish species from Kahramanmaras, Turkey. Environ Int, 31(5): 703711, doi: 10.1016/j.envint.2005.01.002.

George, D., Mallery, M. (2010). SPSS for windows step by step: a simple guide and reference, 17.0 update. 10a Ed. Pearson, Boston, UK.

Gökalp, H.Y., Kaya, M. (1993). Et ve et ürünlerinde kalite kontrolï ve laboratuvar uygulama kilavuzu. Atatürk Üniversitesi Ziraat Fakültesi Ofset Tesisi, Erzurum, Türkiye.

Güneş, M. (2007). Tercan Baraj Gölü ve Tuzla Çayı'nda yasayan Capoeta Capoea Umbla Heckel, 1843 populasyonlarının baz1 biyo-ekolojik özellikleri, total yă̆ ve yağ asidi kompozisyonlarının karşılaşturılması. Atatürk Üniversitesi Fen Bilimleri Enstitüsü Su Ürünleri Anabilim Dalı Doktora Tezi, Erzurum, Türkiye, $115 \mathrm{~s}$.

Kaçar, S., Başhan, M., Oymak, S.A. (2018). Chondrostoma regium'un kas ve gonad dokusu total lipit, fosfolipit ve triaçilgiserol yağ asidi kompozisyonu. Kahramanmaraş Sütçü Imam Üniversitesi Tarm ve Doğa Dergisi, 21(1): 20-25, doi: 10.18016/ksudobil.292857.

Kara, C. (2001). Sir baraj gölü (Kahramanmaras,'nde yaşayan Chondrostoma regium (Heckel, 1843)'un diși ve erkek bireylerinin kas dokusu yağ asitlerinin değsisimi. Fen ve Mühendislik. Dergisi, 4(1): 74-78.

Kaya, H. (2017). Munzur Nehri'nde yaşayan Capoeta umbla (Heckel, 1843) ve Chondrostoma regium (Heckel, 1843)'un total lipit ve yağ asitlerinin mevsimsel değişimi. Dicle Üniversitesi Fen Bilimleri Enstitüsü Biyoloji Anabilim Dalı Doktora Tezi, Diyarbakır, Türkiye, 307s.

Köprücü, K., Özdemir, Y. (2003). Capoeta capoeta umbla (Heckel, 1843)'nın Keban Baraj Gölü ve Hazar Gölü (Elazığ)'nde yaşayan populasyonlarının et verimi ve bazı büyüme Özelliklerinin karşılaştırılması. Su Ürünleri Dergisi, 20(3-4): 337-343.

Olgun, M., Başçiftçi, Z.B., Ayter, N.G., Kutlu, İ., Akın, A., Karaduman, Y., (2013). Ekmeklik buğday (Triticum aestivum l.) çeşitlerinde protein 
oranının üç farklı analiz yöntemine göre karşılaştırılması üzerine bir araştırma. Süleyman Demirel Üniversitesi Ziraat Fakültesi Dergisi, 8(2): 8087.

Oymak, A.S. (2001). Atatürk Baraj Gölü'nde yaşayan Chondrostoma regium (Heckel, 1843)'un üreme biyolojisi. Süleyman Demirel Üniversitesi Fen Bilimleri Enstitüsü Dergisi, 5(1): 166-175.

Özyllmaz, A., Erguden, S.A., Erguden, D., Özeren, A., Semerci, R.S.N. (2016). The proximate compositions, carbohydrate contents and energy values of three freshwater fish from Seyhan River in Adana/Turkey. Journal of Entomology and Zoology Studies, 4(4): 1153-1155.

Türkdoğan, K. (2012). Üst sindirim sistemi kanserlerinde diyet ve çevresel faktörlerin rolü: Doğu anadolu gerçeği. Sağhlk Düşüncesi ve Tip Kültürü Dergisi, 21: 56-59. 